Niepełnosprawność. Dyskursy pedagogiki specjalnej

Nr 27/2017

Disability. Discourses of special education

No. $27 / 2017$

Amadeusz Krause

Uniwersytet Gdański

\title{
Budowanie wiedzy w pedagogice specjalnej
}

Artykuł opisuje niektóre niekorzystne mechanizmy w procesie budowania wiedzy w pedagogice specjalnej. Jako podstawa analizy krytycznej służy odwołanie się błędów metodologicznych w prowadzeniu badań; do jakości publikacji na gruncie pedagogiki specjalnej; do sposobów pisania podręczników akademickich, do recenzowania monografii i prac awansowych.

Słowa kluczowe: pedagogika specjalna, budowanie wiedzy, jakość publikacji

\section{Knowledge building in special education}

The article discusses some unfavourable mechanisms observed in the process of knowledge building in special education. The critical analysis in the text is based on the following points: methodological mistakes in research; the quality of publications in the discipline of special education, including the ways / practices academic handbooks are written and worked out; reviewing monographs and promotion of scientific works.

Keywords: special education, knowledge building, quality of publications

\section{Wprowadzenie}

W swoich wcześniejszych pracach zwracałem uwagę zarówno na paradygmatyczność wiedzy naukowej, jak i na komplikacje zdefiniowania, rozpoznania i zaszeregowania wiedzy paradygmatycznej w naukach społeczno-humanistycznych. Poszukiwania współczesnych paradygmatów w pedagogice specjalnej wymagało wyjścia poza Kunowską mapę budowania wiedzy i znajdowania objaśnień kompromisowych, typowych dla dyscyplin miękkich, niepoddających się jednoznacznym przyporządkowaniom. Dla jednych ta atypowość humanistyki i nauk społecznych (w tym pedagogiki) jest kluczem do jej dewaluacji, dla innych dowodem na ich wielość paradygmatyczną, wręcz sieć paradygmatów w nich dominujących, równoległych, przeciwstawnych, opozycyjnych itd. W zależności od tego czy poszlibyśmy w rozważaniach w stronę heterogeniczności (pluralizmu) 
współczesnych teorii pedagogicznych [por. Paulston 2000] czy ich naprzemienności [por. Kuhn 2001], ciągle aktualne będzie pytanie o strategie budowania wiedzy we współczesnej pedagogice. Po latach rozmyślań i prób paradygmatycznego uporządkowania wiedzy w pedagogice specjalnej (również po dyskusjach, debatach czy wręcz konieczności tłumaczenia się z takiej a nie innej wizji rozwoju dyscypliny) odważę się postawić tezę o jej częściowej apardygmatyczności.

Uważam, że ciągle duża część tzw. opracowań naukowych w pedagogice specjalnej powstaje $w$ trudnym do określenia paradygmacie (możliwe, że żadnym), a jej napędem nie jest ani rewolucja naukowa, ani przemyślana strategia rozwoju nauki, lecz przypadkowość, nieład teoretyczny, niestaranność metodologiczna. W konsekwencji, odnosząc sie do tytułu, należałoby powiedzieć o budowaniu niewiedzy w pedagogice specjalnej, lub czegoś co tą wiedzę ma imitować. Oczywiście można by pójść śladem różnych badaczy i próbować ustalić, czy nie mówimy tu bardziej o tworzeniu elementów wiedzy potocznej, aniżeli naukowej [por. Leppert 1996]. Nie chciałbym tego w tym tekście rozstrzygać. Dla pedagogiki ważna jest cecha wiedzy tworzonej przez profesjonalistów. Niezależnie od stopnia jej naukowości odgrywa ona istotną rolę $\mathrm{w}$ budowie społecznego wizerunku osoby niepełnosprawnej. Najlepszym przykładem są pojęcia tworzone przez badaczy, które z czasem nabierają swoistych znaczeń w języku potocznym, np. imbecyl, down. Jednakże zjawisko przechodzenia wiedzy naukowej do wiedzy potocznej przy tak uspołecznionych kategoriach jak norma, upośledzenie, niepełnosprawność, jest o wiele większe i groźniejsze. Poprzez grupy profesjonalistów i ich czytelników (głównie studentów i rodziców) budowany jest książkowy katalog cech człowieka niepełnosprawnego, mogący nie tyko potwierdzać istniejące stereotypy, ale i tworzyć nowe. Tak jest między innymi z przekonaniem o agresywności i nadpobudliwości seksualnej osób z niepełnosprawnością intelektualną. Przykładowo jeśli w mało przemyślany sposób tytułuje się swoją książkę Agresja u osób z lekką niepetnosprawnościa intelektualna [Żywanowska 2009], to można oczekiwać wzmocnienia społecznej kategorii agresji w odbiorze tej grupy osób. Podobnie, analogicznie gdybyśmy np. wydali monografię naukową pt. Agresja wśród pracowników naukowych uczelni wyższych.

\section{Pedagogika specjalna a specyfika budowania wiedzy naukowej}

Analizując zjawisko, nazwę je umownie budowaniem niewiedzy lub łagodniej mówiąc, pewnego nieporządku epistemologicznego i metodologicznego w konstruowaniu wiedzy w pedagogice specjalnej, należy przyjąć dwa proste założenia. Pierwsze o narastającej komplikacji budowania wiedzy we współczesnej pedago- 
gice, z wielością wzorców metodologicznych, z upadkiem dominacji racjonalnego obiektywizmu na rzecz rozszerzania pola badań interpretatywnych i oglądu subiektywnych znaczeń jednostkowych. Drugie założenie dotyczy jakości badań pedagogicznych, a w szczególności tezy, iż w całej pedagogice i w każdej jej subdyscyplinie mamy do czynienia z licznymi pracami, którym trudno przypisać, pomimo aspiracji ich autorów, status wiedzy naukowej ${ }^{1}$.

Budowanie wiedzy w pedagogice specjalnej, ze względu na swój interdyscyplinarny rodowód, skłania wielu badaczy do tezy o jej specyfice metodologicznej i teoretycznej. Nie jest to zjawisko atypowe. W wielu subdyscyplinach pedagogiki możemy usłyszeć argumentację na rzecz specyfiki ich niepowtarzalności, odmienności przedmiotu i podmiotu badań. W pedagogice specjalnej argument ten jest wzmacniany tradycją badan medycznych, które nie tylko dominowały w momencie powstawania tej sybdyscypliny naukowej, ale też są obecne w niej po dzień dzisiejszy. O ile trudno byłoby mówić o odmienności metodologicznej pedagogiki specjalnej, to zapewne pod wpływem badań klinicznych i czerpania $\mathrm{z}$ nauk medycznych osiągnęła ona niespotykaną $\mathrm{w}$ innych subdyscyplinach pedagogiki swoistą interdyscyplinarność. Ta interdyscyplinarność jest wprawdzie niewątpliwą zaletą pedagogiki specjalnej i jest niezbędna dla omawiania pedagogicznych oraz funkcjonalnych aspektów jednostek chorobowych czy procesu rehabilitacyjnego, jednak z punktu widzenia metodologicznego może sprawiać kłopoty. Oczywiste jest, że w pracach pedagogów specjalnych jest miejsce zarówno na odkrywanie i wyjaśnianie, na zobiektywizowane badania kliniczne, jak i interpretacyjne rozumienie świata z subiektywnej perspektywy podmiotu. Pytanie czy ta specyfika badawcza upoważnia do opracowania innych standardów metodologii pedagogiki specjalnej?

Analizując argumenty na temat specyfiki pedagogiki specjalnej odróżniającej ją od innych subdyscyplin pedagogiki trudno się z częścią z nich nie zgodzić. Badanie zjawiska niepełnosprawności ma swój wymiar etyczny i najczęściej jednostkowy. Jedynie cześć zjawisk związanych z niepełnosprawnością jesteśmy w stanie prześledzić w strategiach obiektywistycznych, jeszcze mniej w tzw. porównywalnych badaniach ilościowych. Słusznie zwracamy uwagę, że doświadczanie niepełnosprawności ma charakter wysoce subiektywny i interpretatywny. Trudno o porównania poszczególnych klinicznych przypadków, a próby ich ujmowania w statystykach czy prawidłowościach grupowych nierzadko nie tylko spłycają zagadnienie, ale też wypaczają jego istotę. Przykładem są niektóre podręcznikowe opisy najbardziej typowego zespołu genetycznego, jakim jest zespół Downa. Opisy ilościowe i próby budowania wiedzy oparte na wskaźnikach

1 Należy przy tym zaznaczyć, że nie jest to swoisty problem dyscypliny pedagogika, ale problem większości dyscyplin z obszaru nauk społecznych i humanistycznych zobligowanych procesem parametryzacji do ilościowego pomnażania dorobku. 
obiektywistycznych prowadzą często nie tylko do niekorzystnych dla tych ludzi uogólnień, ale i wypaczają spojrzenie na indywidualną perspektywę osoby. W podręcznikowym przekazie nierzadko konkluzje z tak zobiektywizowanych analiz utrwalają wiedzę z zakresu pedagogiki specjalnej, która przyswajana przez studentów, staje się spłyconym obrazem człowieka z zespołem Downa (ryzyko jednostronnej analizy ilościowej możemy także prześledzić, analizując próby ilościowego zbadania niepełnosprawności intelektualnej $\mathrm{w}$ zakresie poziomu pobudliwości emocjonalnej czy seksualnej).

Podobnie problematyczna staje się operacjonalizacja zmiennych $\mathrm{w}$ jednostkach chorobowych czy grupach osób niepełnosprawnych. O ile pewne wąskie obszary funkcjonalne mogą być warunkowane konkretnymi działaniami rewalidacyjnymi (i to z powodzeniem można mierzyć), o tyle postrzeganie całości funkcjonowania człowieka w kontekście niepełnosprawności trudno ująć w wartości liczbowe. Częsty błąd takich badań to postrzeganie człowieka wyłącznie przez pryzmat niepełnosprawności, z pominięciem czynników, które są trudne lub wręcz niemożliwe do kontrolowania w postępowaniu metodologicznym. Typowym przykładem takiej sytuacji jest próba statystycznego ujęcia zachowań agresywnych łączonych z niepełnosprawnością intelektualną, z całkowitym pomięciem cech osobowych badanych. Innym przykładem jest analiza zachowań szkolnych uczniów wyłącznie na podstawie stopnia i zakresu niepełnosprawności.

Tego typu badania nie tylko są w stanie zredukować człowieka do kategorii niepełnosprawności, ale i budować istotne elementy wiedzy (zarówno naukowej, jak i społecznej) o osobach z niepełnosprawnością. Oczywiście te uwagi nie mają na celu podważenia zasadności badań obiektywistycznych, czy - jak je często określamy - ilościowych. Chodzi jedynie o zwrócenie uwagi na ich niedoskonałość i jednostronność, a co a tym idzie, ograniczenia w budowaniu wiedzy o człowieku niepełnosprawnym.

Typowym zjawiskiem dla wielu prac w pedagogice specjalnej, $\mathrm{i}$ to na różnych poziomach rozwoju naukowego, jest powierzchowność badań ankietowych i ich analiza. Często badania te sprawdzane są do prostych wyliczanek procentowych na podstawie niewystandaryzowanych narzędzi badawczych. W części z nich, pomimo iż trudno o zmienne czy wskaźniki, nie brakuje twardych tez końcowych i stwierdzeń w kategoriach obiektywnej prawdy. Wytrawny badacz będzie posiadał instrumenty, by tę głoszoną prawdę zrewidować - przyjrzy się narzędziu, jeśli będzie jego opis, oceni dobór próby badawczej, sposób analizy danych, operacjonalizacji zmiennych czy wskaźników. W przypadku braku tych danych albo odrzuci wyniki tych badań, albo przynajmniej potraktuje je z dużą ostrożnością i ograniczonym zaufaniem. Inną sytuację mamy, gdy dopuszczamy, by wyniki takich badań zagościły na stronach podręczników akademickich. 
Obecnie w wielu obszarach pedagogiki specjalnej przeważają badania jakościowe. Analizując te prace ma się niekiedy wrażenie, że nie zawsze wybór tej strategii badawczej jest podyktowany chęcią poznania jakościowego zjawiska, czasami jest to swoiste antidotum autora na surowe wymogi procedury obiektywistycznej. Często autor badań chciałby osiągnąć cel badania obiektywistycznego za pomocą procedury jakościowej. W tego typu pracach widzimy trudność nie do pokonania przez wielu badaczy, t $\mathrm{j}$. zmianę perspektywy badawczej i uświadomienie sobie konsekwencji metodologicznych tej zmiany. Nie zawsze ten proces się udaje. Mamy prace gdzie przyjęcie określonej strategii badawczej nie znajduje pokrycia w stosowanym języku i rozumowaniu. Ma się wrażenie, że dla niektórych badaczy jedynym argumentem badań jakościowych jest niedostępność wystarczającej liczebnie grupy badawczej. Nierzadko w poważnych projektach badawczych deklaracji interpretatywności towarzyszą obliczenia i wnioskowanie ilościowe. Często w pracy trudno znaleźć próby rozumienia badanej rzeczywistości, świadomości konstruowania wiedzy czy jej kontekstowości, a sam proces badawczy ogranicza się do prostego opisu przypadków i zdarzeń, w których byli uwikłani. Możliwe, że tych problemów byłoby mniej, gdyby rozpowszechnić metodologię jakościowych badań pozytywistycznych tak przydatnych na gruncie pedagogiki specjalnej, w których badacz nie musi udawać interpretatywność, która w sensie badawczym do niczego mu nie jest potrzebna.

Błędy badań ilościowych, jak i jakościowych nie pozostają bez konsekwencji. Publikowane $\mathrm{w}$ tekstach czasopism naukowych i monografiach przyczyniają się do rozpowszechniania wiedzy z punktu naukowego wątpliwej. Szczególnego znaczenia nabiera ona $\mathrm{w}$ podręcznikach akademickich, przyjmowanych przez część odbiorów jako miejsce rozpowszechniania wiedzy naukowej obiektywnej i zweryfikowanej. Niestety założenie takie może być zgubne. Warto przypomnieć, że pedagogice specjalnej nie ma standardów takich podręczników, a ich udział w rozwoju nauki raczej się dewaluuje, aniżeli docenia. To - moim zdaniem - poważny błąd. W praktyce każdy, nawet początkujący badacz, może swoją monografię nazwać podręcznikiem akademickim lub hasłem, który w domyśle do takiego aspiruje typu pedagogika specjalna w zarysie; główne problemy pedagogiki specjalnej; niepetnosprawność intelektualna; dydaktyka pedagogiki specjalnej itp.

Są też przypadki pisania podręczników przez osoby z całkowitym brakiem dorobku, w zakresie którego dotyczą. Nierzadko są to osoby spoza środowiska pedagogów specjalnych, bez pogłębionego doświadczenia i znawstwa problemów osób niepełnosprawnych. Często taki podręcznik ma formę zbioru wszystkiego co napisano na dany temat, a właściwie wszystkiego co autor znalazł na dany temat. Wydaje się, że przykładem monografii, która aspiruje do takiego właśnie podręcznika, jest "Wprowadzenie do pedagogiki inkluzyjnej (włączającej)” [Sipowicz, Pietras 2017]. Pomijam fakt, że w tej mini monografii (111 stron) w wielu 
miejscach pojawiają się stwierdzenia identyfikujące niski poziom wiedzy autorów na temat, o którym piszą, czy fakt przeplatania znalezionych wycinków wiedzy naukowej, z wiedzą potoczną, momentami banalną ${ }^{2}$. Chodzi także o strukturę i zakres tej publikacji. Jest to zbiór siedmiu krótkich artykułów, wprawdzie zbliżonych tematycznie, jednakże bez wyraźnego zamysłu badawczego, badań własnych czy metodologicznie osadzonych analiz teoretycznych. To prywatny, słabo udokumentowany pogląd autorów na inkluzję, aspirujący do „wypetnienia luki w polskich badaniach nad pedagogika inkluzyjnq" (s. 5), chyba jedynie pewnością stwierdzeń typu "Ostania faza rozwojowa pedagogiki specjalnej jest inkluzja” (s. 11) "Tym samym takowe myślenie zostało już dawno wyrugowane z obecnego dyskursu medycznego, czego zdaje się polska myśl pedagogiki specjalnej nie dostrzegać" (s. 17). Tego typu odkrycia autorów wraz z chaotycznie prezentowanymi wycinkami innych publikacji prac na temat inkluzji mają być wprowadzeniem do polskiej pedagogiki inkluzyjnej, której w domyśle nie ma, i oto trzeba ją stworzyć, wypełniając ową lukę w polskiej myśli pedagogicznej. Zapewne ten zamiar spowodował, że nie ma tu podstawowych pozycji z polskiej pedagogiki specjalnej podejmującej zagadnienia edukacji włączającej czy choćby podstawowych podręczników pedagogiki [np. Dykcik 1996; Chrzanowska 2009/2015; Śliwerski 2010]3.

Rzeczywiście słaba byłaby polska pedagogika specjalna, gdyby publikacja ta była w stanie wypełnić w niej jakieś luki. Możliwe jednak, że przekonanie do takiego mniemania dali jej sami pedagodzy specjalni, przyjaźnie recenzując to dzieło. Jedna $\mathrm{z}$ recenzentek pisze:

„Merytorycznie ujmując praca stanowi kompendium uporządkowanej wiedzy na temat nowego wymiaru oddziaływań pedagogicznych"4.

Nic dodać, nic ująć.

W podręcznikach opartych na swoistej sprawozdawczości dzieł pisanych cytowania z połowy ubiegłego wieku przeplatają się z tekstami aktualnymi bez zbytniego namysłu nad czasem, zmianą czy kontekstem. W przypadku braku możliwości weryfikacji takiej wiedzy czy jej odbiór przez nieobeznanego z problemem odbiorcy (najczęściej studenta, czasami rodzica) podręcznik taki staje się źródłem rozpowszechniania wiedzy powierzchownej, spłyconej, a nawet nieprawdziwej, czyli pseudo-wiedzy. Niestety w każdej z działów pedagogiki specjalnej można

2 Np. każde dziecko ma określony talent, s. 12; niechęć polskiej pedagogiki specjalnej względem medycyny, s. 17; gwoli ścisłości należy dodać, że pedagogika enerdowska nie była wolna od indoktrynacji ideologicznej, s. 18; w Polsce nie doczekaliśmy się instytutu, który zajmowałby się stricte pedagogika inkluzyjna, s. 21.

3 Jest natomiast zamiar analizy zjawiska inkluzji wobec paradygmatów pedagogiki specjalnej, gdzie pomieszanie wszystkiego co autorom kojarzy się z paradygmatem np. paradygmat powinnościowy, destygmatyzacji, deinstytucjonalizacji , itp, świadczy zarówno o niezrozumieniu dla tej kategorii naukowej, jak o wybiórczym przyswajaniu desygnatów teorii dla poparcia lansowanej przez siebie tezy np. o "piewcach nieomylności paradygmatu humanistycznego", s. 101.

4 Z recenzji Hanny Żuraw, opublikowanej w książce na stronie 115. 
by takie opracowania wskazać. Możliwe, że należałoby pójść w ślady Bogusława Śliwerskiego i tworzyć katalog książek (nie)godnych czytania [Śliwerski 2017]. Typowe zjawisko budowania takiej pseudo-wiedzy Autor opisuje tak:

„Ktoś, kto przeczytał gdzieś czyjąś myśl, tak się nią zachwycił, że postanowił nadać jej uniwersalny charakter, wyłączając ją z wszelkich kontekstów antropologicznych, aksjologicznych, ontologicznych czy etycznych. Ot, taka mądrość życiowa w pigułce. Właściwie nic nie trzeba dodawać, niczego wyjaśniać. Każdy przecież zrozumie taki urywek czyjeś tezy, bo stając sie banałem, rozpowszechnia się szybciej, niż tekst, z którego myśl została wyrwana” (s. 103) (...) „Tak powstaje wiedza potoczna, właśnie w sposób naturalny, na bazie indywidualnych doświadczeń jej kreatora, który wpisuje w swoją narrację odwołania do codzienności, do tego co jemu samemu sprawdziło się w działaniu" (s. 104).

O słabościach metodologicznych prac pedagogicznych pisano wielokrotnie. Na gruncie pedagogiki specjalnej problem wydaje się jednak marginalizowany. Tym co szczególnie zadziwia, jest fakt, że nadal zdarzają się przypadki wyjątkowej pobłażliwości recenzentów prac awansowych w kwestiach metodologicznych. Trzeba wręcz powiedzieć, że nieporządek epistemologiczny jest przez samych pedagogów specjalnych replikowany. Można wskazać przypadki gdzie błędne założenia metodologiczne, dyskredytujące de facto naukową wartość monografii, są w recenzjach przedstawiane jako drobne błędy warsztatowe. Nierzadko skutkuje to awansem do samodzielności naukowej osób z niską świadomością metodologiczną, co w perspektywie ich uprawnień do promotorstwa doktoratów czy prawa recenzowania w przewodach habilitacyjnych jest szkodliwe dla dyscypliny. Powstaje swoiste perpetuum mobile, gdzie słabość napędza słabość, a pomysłów - jak to koło zatrzymać - brak. Osoby przygotowujące się do swoich pierwszych recenzji awansowych zachęcam do przeczytania dostępnych recenzji na stronie Centralnej Komisji ds. Tytułów i Stopnia Naukowych, a w szczególności do oceny ich wzajemnych rozbieżności czy nieadekwatności do rzeczywistej wartości dzieła. Zachęcam również do odwagi w wydawanych opiniach.

Szkodę wyrządzają nie tylko recenzenci, którzy nie dostrzegają wad metodologicznych projektów, ale też ci, którzy skrzętnie wyliczając błędy pracy, nie są konsekwentni w swoim wniosku końcowym. Na stronach CK można prześledzić krytyczne recenzje, gdzie trudno znaleźć przesłanki służące do sformułowania pozytywnego wniosku końcowego, a taką właśnie konkluzją te recenzje się niestety kończą. Skutki tak źle pojmowanej wyrozumiałości recenzentów to jedna z przyczyn kryzysu jakości w całej pedagogice. Kryzys ten jest widoczny przede wszystkim na poziomie prac doktorskich, gdzie recenzje negatywne należą do rzadkości. W opinii środowiskowej negatywna recenzja pracy doktorskiej uderza 
w promotora. Tak zapewne jest. Jednakże czy to nie właśnie ta osoba powinna odpowiadać za dopuszczenie gotowej pracy do procedowania?

Drugim istotnym elementem nieporządku budowania wiedzy w pedagogice specjalnej może być specyfika rozwoju kadrowego tej subdyscypliny. Przez dziesięciolecia była ona reprezentowana przez bardzo niewielkie grono samodzielnych pracowników naukowych. Skutkowało to stosunkowo niską reprezantywnością pedagogów specjalnych w ogólnopedagogicznych debatach naukowych, a co za tym idzie, również hermetyczność ich badań. Wąskie grono profesorów danej dziedziny sprzyja wzmacnianiu autorytatywności zarówno badaczy, jak i stanowisk badawczych. Jeśli immanentną cechą budowania wiedzy naukowej jest jej aktualizacja, często weryfikacja lub dezaktualizacja to zjawisko autorytatywności wiedzy będzie w tej aktualizacji przeszkadzać. Możemy ją po dzień dzisiejszy zaobserwować w wielu pracach. Przejawia się ono w zjawisku, które określiłbym „piedestałem - pomnikiem wiedzy”, z którym nie wypada dyskutować i należy go obowiązkowo zaprezentować w każdej książce zbliżonej tematycznie. W najprostszej postaci zjawisko to przybiera formę prezentacji podbudowy teoretycznej łączącej w "jednym worku" nowe i stare "wytwory teoretyczne" dostępne na dany temat, bez określenia paradygmatu w jakim powstały, czy ich społeczno-kulturowego kontekstu.

Przykładem jest tak popularne zagadnienie, jak rodzina z dzieckiem niepełnosprawnym. $\mathrm{W}$ wielu ciekawych projektach badawczych $\mathrm{z}$ tego obszaru czytamy od lat o etapach przystosowania się rodziców do niepełnosprawnego dziecka, postawach rodziców czy konsekwencjach pojawienia się dziecka z niepełnosprawnością $w$ rodzinie. Pomijając fakt, że cytowania na ten temat są już najczęściej wtórne, to takie zbiorcze przedstawienie wszystkich danych z ostatnich 50 lat na temat rodziny, bez uwzględniania kontekstów konstruowania wiedzy, traci dla najnowszych badań swoją przydatność, nawet upoważnia do nieprawdziwych wniosków i porównań. Mówiąc najprościej, czym innym był szok rodziców lat osiemdziesiątych, aniżeli lat dwutysięcznych, inne warunki funkcjonowania rodziny niż obecnie, inne miejsce niepełnosprawności w kulturze itd. Często badacze nie są nawet w stanie zrekonstruować metodologicznej drogi powstawania cytowanej wiedzy czy kontekstu w jakim powstawała, a opierają na niej w całości swoje prace.

Zjawisku, które określiłem autorytatywnością wiedzy, towarzyszy brak polemik i krytycznej debaty naukowej. Cechą dojrzałości dyscypliny naukowej jest jej potencjał krytyczny wobec swojego dorobku, poczynań, a przede wszystkim słabości. W dyscyplinach niedojrzałych dyskusja może być pozorna, polemika odbierana jako personalny atak, a aktualizacji wiedzy jako zamach na autorytety. Zwróćmy uwagę, że w pedagogice specjalnej (także w całej pedagogice) nie ma kultury polemiki naukowej na łamach najważniejszych czasopism ${ }^{5}$. Czytając 
przykładowo artykuły Thomasa Kuhna w prasie zagranicznej, ze zdumieniem obserwowałem liczne dołączane linki artykułów dyskutujących z autorem, czasami wręcz całkowicie się z nim niezgadzających. Ta dojrzałość dyscypliny do krytycznej debaty jest nieodzownym elementem budowania wiedzy naukowej. Tam wieloparadygatyczność nie upoważnia do bezkrytycznego głoszenia czegokolwiek, lecz wymusza konieczność obrony swojego stanowiska na tle swojego paradygmatu.

Możliwe, że przeszkoda budowania kultury dyskusji jest absurdalna, na poziomie klasycznej pustej taczki, z którą tak szybko się jeździ, że nie ma czasu jej załadować. Chodzi o relacje czytelnictwa i piśmiennictwa naukowego w pedagogice. Inaczej mówiąc, nie mamy czasu czytać, bo musimy pisać. Do takich konkluzji może doprowadzić analiza skutków parametryzacji punktowej w szkolnictwie wyższym. W większości uczelni zasady parametryzacji jednostki zostały przeniesione na ocenę pracownika. Brak rozróżnienia dyscyplinarnego w tej procedurze prowadzi do karykatury jakości i rozwoju. Weźmy za przykład pedagogikę specjalną. Załóżmy tylko, że jest około 500 osób pracujących na uczelniach w tym obszarze. Niech każdy z nich zostanie zobligowany do „dostarczenia” swojej jednostce 30 punktów w ciągu 2 lat (najczęściej minimum trzy teksty), to już daje minimum 1500 tekstów w dwóch latach, 3000 - w czterech, 6000 - w ośmiu itd. Pytaniem ważnym jest nie tylko kwestia, kto jest to $\mathrm{w}$ stanie przeczytać, ale i jak dokonać $\mathrm{w}$ tym materiale selekcji. Zewnętrznie narzucone wymogi ilościowe sprzyjają nieetycznym sposobom pomnażania własnego dorobku. Nawet jeśli tego się badacz wystrzega, to zjawisko tzw. wielowątkowego mielenia tego samego zagadnienia buduje pseudowiedzę, wśród której prawdziwą naukę nie sposób już odróżnić. Recenzując dorobek w procedurach awansowych można się przekonać o efektach podporządkowania rozwoju kryteriom ilościowym, tzw. zbieractwa punktowego, np. w postaci rozproszenia twórczości, przypadkowości wyboru tematów badań, powierzchowności analiz, chaotyczności paradygmatycznej, ateoretyczności, wzrostu artykułów wieloautorskich itd.

Krytykując system motywacji zewnętrznej nie możemy zapomnieć, że jest on pewnym narzędziem mającym zapobiegać innym słabościom od lat znanym w pedagogice, to jest zjawisku pozorowania działalności naukowej. $W$ tym kontekście parametryzacja jawi się jako efekt bezradności środowiska wobec tych zjawisk i jest najprostszym narzędziem egzekwowania twórczości. Niestety śmiem twierdzić, że tylko pozornie skutecznym, których negatywnych skutków sobie nie uświadamiamy. W naukach humanistycznych i społecznych to psucie nauk. Czy jest inny sposób weryfikacji działalności naukowej w tych dyscyplinach? Przykłady z innych krajów o dojrzałej kulturze naukowej zwracają uwagę na

$\overline{5}$ Nielicznym wyjątkiem jest cytowana wcześniej praca Bogusława Śliwerskiego 
faktyczne kryteria naukowe twórczości, weryfikowane debatą, merytoryczną oceną, a nie punktami. Wśród tych krajów należy poszukiwać rozwiązań projakościowych, a mając na uwadze ich doświadczenia, wystrzegać się popełnionych błędów (np. komercjalizacji rankingów, baz naukowych gdzie opłaty decydują o przyjmowaniu tekstu do druku). Niezależnie jakie sposoby wybierzemy, będą one wymagały uporządkowania twórczości pedagogów (o ile taki proces w ogóle jest jeszcze możliwy). Będą one oznaczać dojrzałość naukową dyscypliny, gdzie nie ma miejsca na koniunkturalizm jednostki naukowej (typu „swoich puszczamy obcych oblewamy"), na koleżeńskie recenzje, na ametodologiczność badań. Gdzie nie akceptuje się sytuacji, że odkrycie plagiatu przysparza więcej problemów recenzentowi aniżeli autorowi; gdzie wycofanie dorobku przed oceną komisji habilitacyjnej będzie postrzegane jako zjawisko nieetyczne o istotnej szkodzie społecznej; gdzie z dobrych dydaktyków na siłę nie będzie się robiło kiepskich naukowców; gdzie polemika naukowa oddzieli naukowców od pozorujących naukę, aż wreszcie gdzie pozycja środowiskowa, ocena ekspercka będzie podstawą oceny twórczości badacza, a nie przypisane mu punkty.

\section{Zakończenie}

Wielość wątków budowania wiedzy w pedagogice specjalnej powinna mobilizować badaczy by temu zagadnieniu poświęcić więcej uwagi. Zapewne będzie wymagało to pewnej perspektywy krytycznej wobec powstających publikacji w pedagogice specjalnej. Nie uważam, żeby to było zjawisko złe. Krytycznej debaty naukowej nie należy postrzegać jako mechanizmu deprecjacji pedagogiki specjalnej, lecz jako obronę przed taką deprecjacją. Dopóki ta subdyscyplina nie wytworzy naukowych i środowiskowych mechanizmów oczyszczania się z pseudowiedzy i pseudonaukowców, dopóty będzie obiektem zarzutów w kwestiach swojej naukowości.

\section{Bibliografia}

Chrzanowska I. (2009), Zaniedbane obszary edukacji - pomiędzy pedagogiką ogólna a pedagogikq specjalną, Kraków.

Chrzanowska I. (2015), Pedagogika specjalna, od tradycji do wspótczesności, Kraków.

Dykcik W. (1996), Pedagogika specjalna, Poznań.

Leppert R. (1996), Potoczne teorie wychowania studentów pedagogiki, Bydgoszcz.

Kuhn T. (2001), Struktura rewolucji naukowych, Warszawa.

Sipowicz K., Pietras T. (2017), Wprowadzenie do pedagogiki inkluzyjnej (wtączajacej), Wrocław.

Śliwerski B. (2010), Pedagogika, t. 4, Gdańsk. 
Śliwerski B. (2017), Książki (Nie)godne czytania?, Kraków.

Paulston G.R. (2000), Pedagogika porównawcza jako pole nakreślenia konceptualnych map teorii i paradygmatów [w:] Alternatywy myślenia o edukacji, Z. Kwieciński (red.), Warszawa. Żywanowska A. (2009), Agresja wśród osób z lekką niepetnosprawnością intelektualną, Kraków. 